\title{
ANALYSIS OF THE DIURNAL EXPRESSION PATTERNS OF THE TOMATO CHLOROPHYLL $a / b$ BINDING PROTEIN GENES. INFLUENCE OF LIGHT AND CHARACTERIZATION OF THE GENE FAMILY*
}

\author{
J.-W. Kellmann ${ }^{1}$, E. Pichersky ${ }^{2}$ and B. Piechulla ${ }^{1 \dagger}$ \\ ${ }^{1}$ Institut für Biochemie der Pflanze, Untere Karspüle 2, 3400 Göttingen, W. Germany and ${ }^{2}$ Biology \\ Department, University of Michigan, Ann Arbor, MI 48109, USA
}

(Received 1 October 1989; accepted 2 January 1990)

\begin{abstract}
Steady-state mRNA levels of the chlorophyll $a / b$ binding ( $c a b$ ) proteins oscillate substantially during a diurnal cycle in tomato leaves. This accumulation pattern is also observed in complete darkness, supporting the hypothesis that the expression of $c a b$ genes is at least partially regulated by an endogenous rhythm ("biological clock"). The amplitude of the cab mRNA accumulation is dependent on the duration of illumination and the circadian phase in which light was applied to the tomato plants. These results at the molecular level correlate well with the photoperiodic phenomenon. The characterization of the expression pattern of individual members of the $c a b$ gene family was attempted. Distinct primer extension products were detected using specific oligonucleotides homologous to the $c a b 1, c a b 4, c a b 5$ and $c a b 8$ genes. Based on this analysis the transcription start sites of these genes were determined to be between position -70 and -9 upstream of the ATG codon. During the diurnal cycle the $c a b 1$ and $c a b 4$ genes exhibit the same expression pattern; no transcripts detected at 3 and 6 a.m., maximum mRNA levels were measured at noon and decreasing levels in the afternoon.
\end{abstract}

\section{INTRODUCTION}

Primary reactions of photosynthesis accomplish the capturing and distribution of light energy. For this purpose the photosynthetic apparatus of the plants is equipped with a specific type of protein, the light harvesting chlorophyll $a / b$ binding $(c a b) \ddagger$ polypeptides. This distinct class of proteins is characterized by their ability to bind chlorophyll and their association with the light harvesting complexes of photosystem I and II, localized in the thylakoid membranes. In many plant species several of these proteins and their respective genes have been isolated and characterized. At least two types of the $c a b$ proteins were localized in the light harvesting complex II, while four types are designated to complex I (Darr et al., 1986; Evans and Anderson, 1986; Hoffman et al., 1987; Pichersky et al., 1989). At present the coordinations of the chlorophyll and protein biosynthesis pathways and the stoichiometries of pigment-protein interactions of each $c a b$ protein are not well understood. In order to enlighten some aspects of this complex biogenesis, we started a characterization at the molecular level. At present 15 genes coding for various $c a b$ proteins have been identified in the species Lycopersicon esculentum, the plant in which the gene family has been investigated most extensively. In tomato, four genes are localized on chromosome 2 (designated $c a b$ 1A-D;

\footnotetext{
* Dedicated to Steve Reich.

$\dagger$ To whom correspondence should be addressed.

$\ddagger$ Abbreviations: $c a b$, chlorophyll $a / b$ binding proteins; MMLV, reverse transcriptase, reverse transcriptase of Moloney mouse leukemia virus; $r b c S$, small subunit of ribulose-bisphosphate carboxylase.
}

Pichersky et al., 1985), one gene on chromosome 8 (cab 2; Pichersky et al., 1985), three genes and a truncated gene on chromosome 3 ( $c a b$ 3A-C,T; Pichersky et al., 1985), one gene on chromosome 7 (cab 4; Pichersky et al., 1987b), one gene on chromosome 12 ( $c a b$ 5; Pichersky et al., 1987b), two genes on chromosome 5 (cab 6A/B; Pichersky et al., 1987a; Hoffman et al., 1987), and two genes on chromosome 10 ( $c a b$ 7; Pichersky et al., 1988; cab 8 ; Pichersky et al., 1989). However, beside the structural and organizational characterization, very little is known about the expression pattern and the regulation of the expression of this gene family in tomato.

It is well documented that these genes are expressed in a tissue and organ-specific manner (Pichersky et al., 1985, 1987a,b, 1988, 1989); specific $c a b$ mRNAs are generally detected in green tissues of the tomato plant, while in the non-green tissues, such as roots, anthers and petals no transcripts were monitored. This finding is also valid for other plant species (Kuhlemeier et al., 1987). In addition, the products of these genes accumulate differentially depending on the developmental stage of the organ (Piechulla et al., 1986; Piechulla and Gruissem, 1987). Light is also known to substantially influence the expression of the $c a b$ genes (for review Kuhlemeier et al., 1987). This summary demonstrates clearly that a very complex expression pattern of the $c a b$ genes was/is established in plants. In addition to light- and tissue-specific expression, diurnal and circadian $c a b$ mRNA accumulation patterns were observed in tomato fruits as well as in other organs of other plant species (Piechulla and Gruissem, 1987; Kloppstech, 1985; Spiller et al., 1987; Nagy 
et al., 1988; Guiliano et al., 1988a,b; Paulsen and Bogorad, 1988; Taylor, 1989; Stayton et al., 1989; Meyer et al., 1990), indicating that $c a b$ gene expression is indeed a complex process.

From several reports (Piechulla, 1988, 1989; Meyer et al., 1990) it is clear that the different parameters that influence the expression of the $c a b$ genes cannot be investigated separately from each other; these factors all contribute to a particular $c a b$ steady-state mRNA level in a coordinated fashion. For example, light induces $c a b$ mRNA accumulation but also plays an important role in the exhibition of the circadian rhythmicity (Meyer et al., 1990; Riesselmann and Piechulla, 1990). The correlation of the effect of light and light/dark transitions with the diurnal expression pattern will be reported in the first part of this paper. Secondly, we have begun to dissect the $c a b$ gene family to analyse each member of the family separately in respect to their specific circadian expression pattern. Since the nucleotide sequences of the members of the $c a b$ gene family in tomato are known, the primer extension technique has been chosen for this particular analysis.

\section{MATERIALS AND METHODS}

Plant material and tissue preparation. Tomato plants (Lycopersicon esculentum, cherry line, cv. VFNT LA 1221, CM. Rick, UC Davis, CA or Gardeners Delight, Yates, Spalding, Lincolnshire PE11 1BP, UK) were grown in soil in the greenhouse or on clay beads (average diam. $0.5 \mathrm{~cm}$ ) in the growth chamber at the University of Göttingen, and watered with tap water or Hoagland's nutrient solution, respectively. In the greenhouse, supplementary light was given from $6 \mathrm{a} . \mathrm{m}$. to 8 p.m. during the winter time (October to mid May). Plants in the growth chamber were illuminated with $14 \mathrm{~h}$ white light $\left(20 \mathrm{~W} \mathrm{~m}^{-2}\right)$; the temperature was altered between $22^{\circ} \mathrm{C}$ during illumination and $15^{\circ} \mathrm{C}$ during the dark phase.

Experiments $l$ and 2. Tomato seedlings (Gardeners Delight) were grown for 11 days in the growth chamber at a $14 \mathrm{~h}$ light $/ 10 \mathrm{~h}$ dark regime and then transferred into continuous darkness. Light pulses were given at $6.30 \mathrm{a} . \mathrm{m}$. to $8.30 \mathrm{a} . \mathrm{m}$. and $6.30 \mathrm{a} . \mathrm{m}$. to $10.30 \mathrm{a} . \mathrm{m}$., respectively. Leaves were harvested at 6.30 a.m., 7.30 a.m., 8.30 a.m., 10.30 a.m., 12.30 p.m., 3.30 p.m., 6.00 p.m. and 10 p.m.

Experiment 3. Tomato plants (VFNT LA 1221) were grown hydroponically for 4 weeks under the natural day/ night cycle (May 1988) and then transferred into the growth chamber $\left(14 \mathrm{~h}\right.$ light, $76 \mathrm{~W} \mathrm{~m}^{-2}$, beginning of illumination: $6.30 \mathrm{a} . \mathrm{m}$.) for 5 days. Two individual tomato plants were transferred into light for $4 \mathrm{~h}$ at different times during the day: $6.30 \mathrm{a} . \mathrm{m} ., \quad 9.00 \mathrm{a} . \mathrm{m} ., \quad 11.00 \mathrm{a} . \mathrm{m}$. 1.00 p.m., 5.00 p.m., 8.00 p.m., midnight and 4.30 a.m. Leaves were harvested $10 \mathrm{~min}$ before transfer time and $4 \mathrm{~h}$ later.

Experiments 4 and 5. Tomato plants (Gardeners Delight) were grown for 4 months (11 November 1988 to 11 March 1989) in the greenhouse. Leaves were harvested at $11.00 \mathrm{a} . \mathrm{m}$. Tomato plants (VFNT LA 1221) were grown for 71 days in the greenhouse and leaves were harvested in May (1989, sunrise: 4.29 a.m., sunset: 8.09 p.m.) at 3.00 a.m., 6.00 a.m., 9.00 a.m., 12.00 a.m., 3.00 p.m, and $6.00 \mathrm{p} . \mathrm{m}$. In both cases the harvest included only leaves of the logarithmic growth phase (max. $2.5 \mathrm{~cm}$ of the terminal leaflet, Meyer et al., 1990).

The tissue was immediately frozen in liquid nitrogen and stored at $-50^{\circ} \mathrm{C}$ until further use.
$R N A$ isolation and steady-state $m R N A$ level quantitation. RNA was isolated from 200 to $500 \mathrm{mg}$ leaf tissue according to the method described elsewhere (Piechulla et al., 1986). RNA of different preparations were standardized and analysed by spectrophotometric quantitation, ethidium bromide fluorescence of the cytoplasmic rRNAs in stained formaldehyde gels. Total RNA samples were spotted onto nylon filters using a dot biot apparatus. A specific gene probe $(0.55 \mathrm{~kb}$ PvulI-HincII fragment of the plasmid pIA27) encoding the $c a b 1 \mathrm{~B}$ gene of tomato (Pichersky et $a l ., 1985)$ was labelled by "random priming" and used for hybridizations. To determine steady-state mRNA levels, dots were cut out and counted in a scintillation counter ("Cerenkov counting"). The relative mRNA levels were calculated based on two or more hybridizations.

RNA isolation and primer extension analysis. RNA was extracted based on the description of Maniatis et al. (1982). Two to $3 \mathrm{~g}$ leaf material was homogenized in liquid nitrogen, extracted with $7 \mathrm{~m} \ell$ of GTC-buffer [ $4 M$ guadinium isothiocyanate (Fluka, Buchs, Switzerland, purity grade: larger than $99 \%), 25 \mathrm{~m} M$ sodium citrate, pH 7.0, $0.5 \%$ sarkosyl, $10 \mu \ell \beta$-mercaptoethanol $(14.2 M)$ per $\mathrm{m} \ell$ extract] and centrifuged $20 \mathrm{~min}$ at $8000 \mathrm{rpm}$ (SS34, $20^{\circ} \mathrm{C}$ ). The supernatant was layered onto a $\mathrm{CsCl}$ cusion $(5.7 M \mathrm{CsCl}, 50 \mathrm{~m} M$ Tris, pH $8.0,5 \mathrm{~m} M$ EDTA, $5 \mathrm{~m} M$ sodium acetate) and centrifuged for $16 \mathrm{~h}$ at $24000 \mathrm{rpm}$ (SW 28, room temperature). The clear pellet was washed twice with $3 M$ sodium acetate, and resuspended in $\mathrm{H}_{2} \mathrm{O}$. To dissolve RNA properly, the solution was heated for 5 min at $65^{\circ} \mathrm{C}$, spun down for 5 min and the supernatant was precipitated with ethanol. RNA was analysed by spectrophotometric quantitation and ethidium bromide fluorescence of the rRNAs in stained formaldehyde gels.

Labelling of the oligonucleotide. Two picomoles gelpurified oligonucleotide (17- to 23-mers) was labelled with $9 \mu \mathrm{Ci} \gamma-\left[{ }^{32} \mathrm{P}\right] \mathrm{ATP}\left(3000 \mathrm{Ci} \mathrm{mmol}^{-1}\right)$ and 7 units polynucleotide kinase (Biolabs, Beverly, MA) in PNK-buffer (100 mM Tris, pH 7.6, $20 \mathrm{mM} \mathrm{MgCl}_{2}, 30 \mathrm{~m} M$ DTT) for $3 \mathrm{~h}$ at $37^{\circ} \mathrm{C}(10 \mu \ell$ reaction volume). The reaction was stopped by heating $2 \mathrm{~min}$ at $95^{\circ} \mathrm{C}$ and the addition of $10 \mu \ell \mathrm{H}_{2} \mathrm{O}$. The labelled oligonucleotide was stored at $-20^{\circ} \mathrm{C}$.

Annealing reaction. Ten to $60 \mu \mathrm{g}$ of total RNA was incubated together with 12.5 units RNAsin (Boehringer Mannheim, Mannheim, W. Germany) and 0.2 pmol kinased oligonucleotide in $250 \mathrm{mM} \mathrm{KCl}, 10 \mathrm{mM}$ Tris (pH 7.9) buffer for $3 \mathrm{~h}$ at the appropriate temperature(s) in an eppendorf vial (final volume of $10 \mu \ell$ ).

Primer extension reaction. Ten microlitres 5-fold concentrated primer extension buffer $(5 \times: 250 \mathrm{~m} M$ Tris, $\mathrm{pH}$ $8.3,125 \mathrm{~m} M \mathrm{KCl}, 15 \mathrm{~m} M \mathrm{MgCl}_{2}, 50 \mathrm{~m} M$ DTT), $500 \mu M$ dNTPs of each nucleotide, $5 \mu \mathrm{g}$ RNase-free BSA (Boehringer Mannheim), $2.5 \mu \mathrm{g}$ Actinomycin and 200 units MMLV reverse transcriptase (200 units/ $\mu \ell$, BRL) per $10 \mu \mathrm{g}$ total RNA and $40 \mu \ell \mathrm{H}_{2} \mathrm{O}$ were combined in the annealing assay and incubated at $37^{\circ} \mathrm{C}$. After $\mathrm{l} \mathrm{h}$ the reaction was stopped by addition of $10 \mu \ell$ of $0.2 \mathrm{M}$ EDTA. The RNA-primer extended hybrid was ethanol precipitated and analysed on 8 or $10 \%$ polyacrylamide urea sequencing gels. No significant difference was observed, whether or not RNA was hydrolysed prior to loading onto the PAU gels. The lengths of the primer extension products were calculated using the pBR322 plasmid-HpaII restriction enzyme fragments, which were labelled at the $5^{\prime}$ ends.

\section{RESULTS}

\section{Influence of light on the circadian cab expression}

Figure 1 presents a typical diurnal cab expression pattern of tomato plants which were grown in a $14 \mathrm{~h}$ light $/ 10 \mathrm{~h}$ dark cycle in the growth chamber. Before and after illumination only very low steady-state 


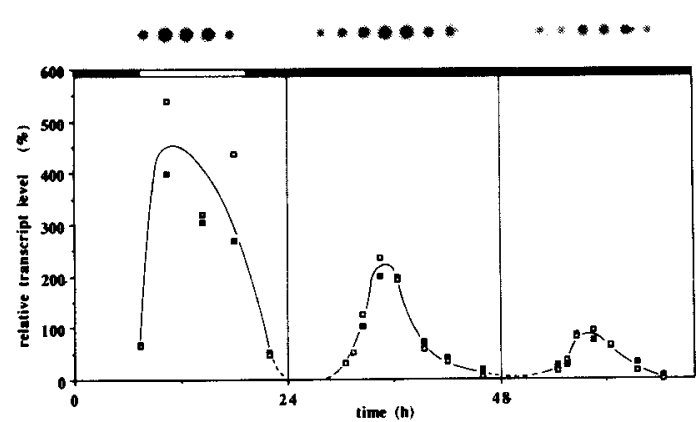

Figure 1. Relative steady-state mRNA levels in tomato seedlings (Gardeners Delight) grown in a $14 \mathrm{~h}$ light $/ 10 \mathrm{~h}$ dark regime and in continuous darkness. Leaves of 12 day old seedlings were harvested at indicated time points and RNA was hybridized with a probe encoding the $c a b$ 1B gene. Light and dark phases are indicated by open and solid bars, respectively. Data of two hybridizations are presented.

mRNA levels were measured. The transcript levels increased about 10 -fold after the transition from darkness to light, and maximum accumulation was reached approximately at noon. Although light continued to be present in the afternoon, the cab transcript levels decreased gradually. Interestingly, this characteristic accumulation pattern remained present on consecutive days if plants were kept in continuous darkness. A typical damping of the amplitude was observed, documented by the reduction of approximately 50 and $80 \%$ on the first and second day in darkness, respectively. This alteration of the amplitude in conditions without environmental perturbations is a strong indication that an endogenous rhythm is involved in $c a b$ gene expression. However, at present nothing is known about the oscillator or the regulatory mechanism.

For further characterization we were interested to find out what effect light or a light pulse has on the circadian mRNA accumulation pattern of the $c a b$ proteins. For this purpose we transferred tomato seedlings into light for either 2 or $4 \mathrm{~h}$ (beginning of illumination at $6.30 \mathrm{a} . \mathrm{m}$.) and determined the mRNA levels [Fig. 2(A,B)]. The typical oscillation pattern was observed in both cases. However, the heights of the amplitudes were found to be different. After $2 \mathrm{~h}$ of light the relative transcript level was increased to $230 \%$ and after $4 \mathrm{~h}$ to $300 \%$. On the following day in complete darkness both amplitudes were reduced to $160 \%$ relative transcript level. Apparently, the 2 or $4 \mathrm{~h}$ light pulses had no differential effect on the $c a b$ mRNA accumulation on the second day of the experiment. Interestingly, the time points of maximum were found to be similar throughout this experiment. This result together with data published by Meyer et al. (1990) indicate that the duration of illumination determines the accumulation amplitude, but does not change the length of the period.

In an additional set of experiments we wanted to find what effect illumination has at different time
A

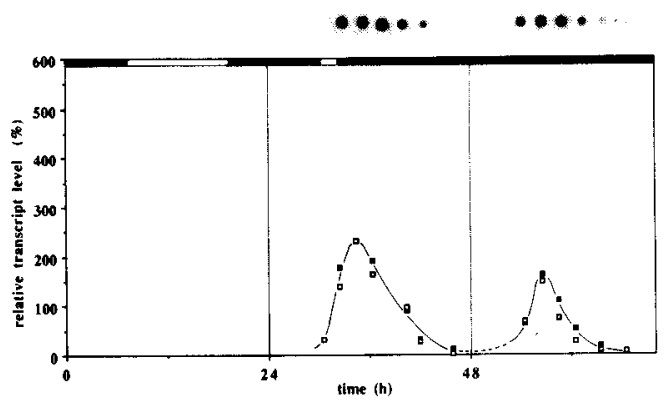

$\mathbf{B}$

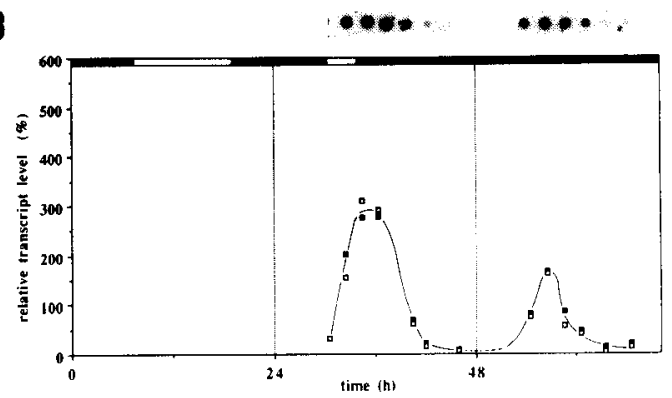

Figure 2. Influence of the duration of light on $c a b$ mRNA accumulation. Relative steady-state mRNA levels in tomato seedlings (Gardeners Delight) were determined after $2 \mathrm{~h}$ (panel A) and $4 \mathrm{~h}$ (panel B) of illumination and in consecutive darkness. RNA extracts were hybridized with a probe encoding the $c a b 1 \mathrm{~B}$ gene. Light and dark phases are indicated by open and solid bars, respectively. Data of two hybridizations are presented.

points during the day. Adult vegetative tomato plants were exposed to $4 \mathrm{~h}$ of light at different circadian times. Leaves were harvested shortly before the transfer to light and $4 \mathrm{~h}$ later. The results of these experiments are depicted in Fig. 3. Plants exposed to light at $6.30 \mathrm{a} . \mathrm{m}$. exhibited highest steady-state mRNA accumulation (approximately $16 \%$ relative transcript level per hour). Minor effects of the light on the accumulation rate $(2-5 \%$ relative transcript level per hour) were recorded in plants illuminated at other time points during the day. The mRNA levels along the dotted line document the level of expression due to the endogenous rhythm. This experiment demonstrates clearly that

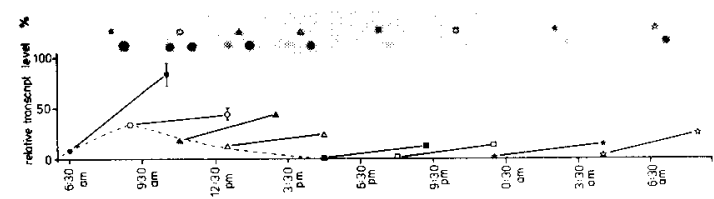

Figure 3. Influence of the circadian time on $c a b$ mRNA accumulation. Tomato plants (VFNT LA 1221) were illuminated for $4 \mathrm{~h}$ at different time points during the day,

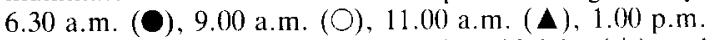
$(\triangle), 5.00$ p.m. (四), 8.00 p.m. ( $\square$ ), midnight $(\star)$ and $4.30 \mathrm{a} . \mathrm{m}$. (放). Steady-state mRNA levels were determined shortly before illumination and $4 \mathrm{~h}$ later. RNA extracts from leaves of tomato plants were hybridized with the $c a b 1 \mathrm{~B}$ gene probe. Relative mRNA levels were based on two hybridizations, error bars represent \pm SE. 
the amplitude of mRNA accumulation is not dependent only on the duration of illumination but also relates substantially to the circadian time.

\section{Expression of individual members of the cab gene family}

The hybridization experiments in the previous section were performed with a probe encoding the $c a b$ 1B gene of tomato. Since the coding regions of the genes of this gene family are very similar to one another (Pichersky et al., 1987a), it is expected that under the experimental conditions used, most, but probably not all, $c a b$ mRNA types hybridized to the gene probe. To determine the expression pattern of each member of the $c a b$ gene family of $L$. esculentum, we have started a detailed analysis using the primer extension technique. This approach was made possible because the nucleotide sequences of $15 \mathrm{cab}$ genes had been determined (Pichersky et al. 1985, 1987a,b, 1988, 1989). Specific oligonucleotides (17to 23-mers) were radioactively labelled and hybridized to total RNA preparations of tomato leaves. The oligonucleotides were elongated in vitro using the reverse transcriptase. The extension was completed at the $5^{\prime}$ end of the specific mRNA. In theory, each $c a b$ mRNA type can be detected and quantitated by this analysis.

A specific oligonucleotide ("cab 1C") complementary to the sequence upsteam of the ATG $(-1$ to -17$)$ of the $c a b 1 C$ gene revealed a major primer extension product comigrating with a DNA marker fragment of 67 bases (Fig. 4). A minor fragment was 65 bases long. Based on this result it is very likely that the transcription start site of this particular gene is at position -67. In addition, another 20-mer oligonucleotide ("cab 1") complementary to the coding region (position +30 to +50 ) of the $c a b 1 \mathrm{~A}-\mathrm{C}$ genes (one mismatch with the $c a b 1 \mathrm{C}$ gene) was used in a primer extension experiment. Three major products of $155 \mathrm{~b}, 117 \mathrm{~b}$, $94 \mathrm{~b}$, and one minor product of $145 \mathrm{~b}$ were detected. Since the oligonucleotide " $c a b 1$ " hybridized exactly 50 nucleotides downstream of the oligonucleotide " $c a b 1 \mathrm{C}$ ", it is likely that the extended product of $67 \mathrm{~b}$ of the previous experiment and the $117 \mathrm{~b}$ fragment resulted from the same $c a b$ mRNA type [Fig. 4(B)]. Further analysis with specific oligonucleotides for the $c a b 1 \mathrm{~A}$ and $c a b 1 \mathrm{~B}$ genes are in progress to designate the other primer extension products.

One important aspect for the quantitative analysis of the primer extension products was the complete detection of the specific mRNA type in the total RNA extracts harvested at different diurnal time points. The hybridization conditions of the RNA with the oligonucleotides have to be adjusted for each combination. Primary experiments regarding the appropriate amounts of the reverse transcriptase and total RNA concentrations were performed. Optimal annealing temperatures of total RNA from
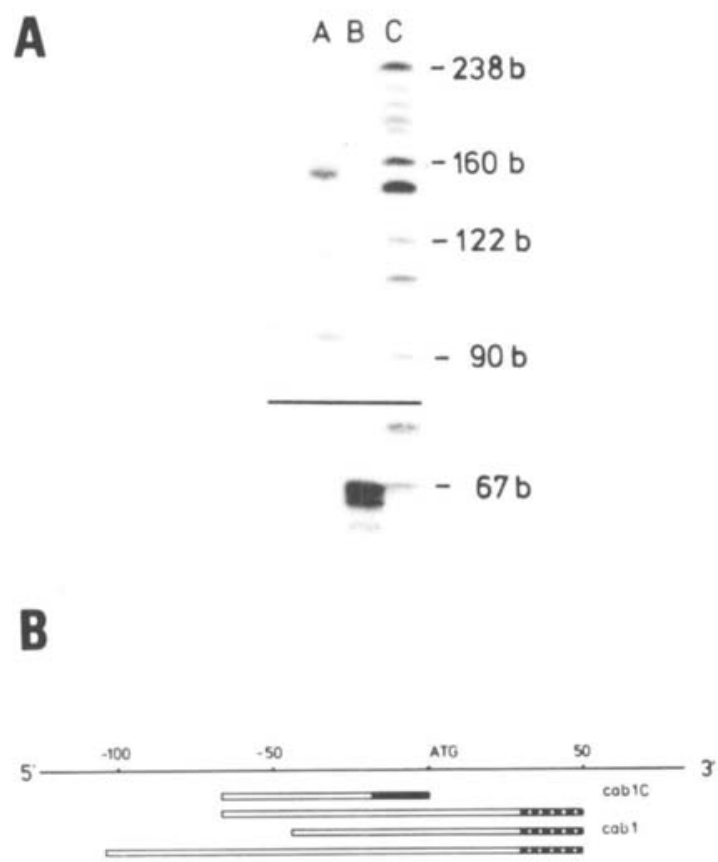

Figure 4. Panel A: primer extension analysis. Total RNA $(40 \mu \mathrm{g})$ from tomato (VFNT LA 1221) leaves were annealed with specific oligonucleotides "cab 1" (lane A) and " $c a b 1 \mathrm{C}$ " (lane B) at 52 and $37^{\circ} \mathrm{C}$, respectively. Lane C: pBR322 digested with HpaII. Panel B: Schematic map of the $c a b 1$ gene. Homologous regions of the specific oligonucleotides (solid or punctured bars) in relation to the $c a b$ gene. The primer extended products are presented by open bars.

Gardeners Delight and each oligonucleotide are shown in Table 1. Furthermore, the primer extension products as well as the respective transcription start sites were listed. The $c a b$ mRNAs analysed so far carry $5^{\prime}$ untranslated sequences ranging in length from 9 to 70 nucleotides.

In addition to the information on structural aspects of the individual genes of the gene family we were also interested in defining their circadian expression pattern. RNA extracts from tomato (VFNT LA 1221) leaves harvested at different time points during the day were hybridized with the specific oligonucleotides, " $c a b 1 \mathrm{C}$ ", " $c a b 1$ " and " $c a b$ 4" (Fig. 5). It was interesting to note that in all three cases no extended primer extension product was detected at 3 and $6 \mathrm{a} . \mathrm{m}$. We therefore concluded that apparently no complementary mRNA species were present, or alternatively, they were under the detection level at this time during the day. Primer extension fragments were detected at 9 a.m., noon, 3 p.m. and 6 p.m., while maximum levels were reached around noon. The $c a b 1$ and $c a b$ 4 transcript accumulation occurred simultaneously after 6 a.m., suggesting that the expression of these two genes is regulated by a similar mechanism.

\section{DISCUSSION}

We have started to analyse the expression patterns of individual members of the $c a b$ gene family 
Table 1. Oligonucleotides used in the primer extension analysis

\begin{tabular}{|c|c|c|c|c|c|c|}
\hline Oligo & $\begin{array}{c}\text { Gene } \\
\text { specificity }\end{array}$ & $\begin{array}{l}\text { Sequence } \\
\left(3^{\prime} \text { to } 5^{\prime}\right)\end{array}$ & $\begin{array}{l}\text { Length } \\
\text { (b) }\end{array}$ & $\begin{array}{c}\text { Annealing } \\
\text { temperature } \\
\left({ }^{\circ} \mathrm{C}\right)\end{array}$ & $\begin{array}{l}\text { Primer extension } \\
\text { products } \\
\text { (b) }\end{array}$ & $\begin{array}{l}\text { Transcription } \\
\text { start site } \\
\text { (position } 5^{\prime} \\
\text { of ATG) }\end{array}$ \\
\hline 1 & $\begin{array}{l}\text { cab } 1 \mathrm{~A} \\
\text { cab 1B } \\
\text { cab 1C (a) }\end{array}$ & GCCTGTCCAGCAAATGAAGG & (20) & $55^{*}$ & $94 / 117 / 155$ & -67 \\
\hline $1 \mathrm{C}$ & cab $1 \mathrm{C}$ & TGTGTTTATATCAAGAG & (17) & $30^{*}$ & $67 / 65(\mathrm{c})$ & -67 \\
\hline 3 & $\begin{array}{l}\text { cab 3A (a) } \\
\text { cab 3B (a) } \\
\text { cab 3C (b) }\end{array}$ & GCCTTTCCGGCGAAAGTAGA & $(20)$ & 52 & 59 & -9 \\
\hline 4 & $\mathrm{cab} 4$ & AATACGGCCTTCACCGAAGTTGC & (23) & $55^{*}$ & $160(c)$ & -58 \\
\hline 5 & cab 5 & GACACGTCCACCTTCAAAGCTAC & (23) & 60 & 140 & -35 \\
\hline 8 & cab 8 & GTTGCCATAATTTCTCTTCTCTT & (23) & 52 & 74 & -66 \\
\hline
\end{tabular}

(a) One mismatch; (b) two mismatches; (c) mRNA exhibits a diurnal expression pattern.

${ }^{*}$ Optimal temperature empirically determined.

A

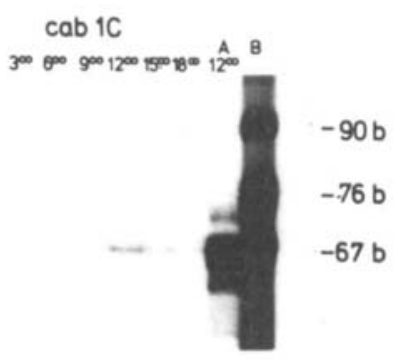

B

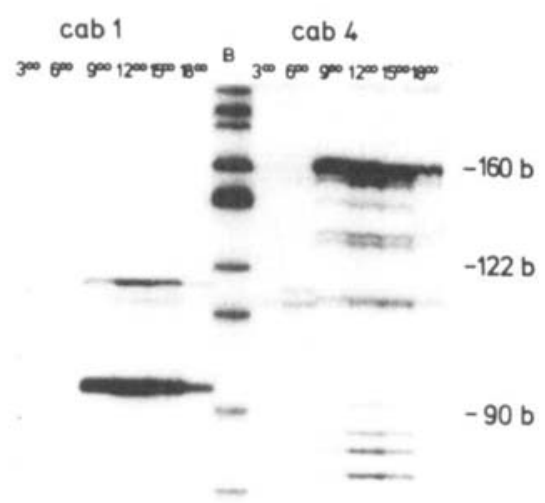

Figure 5. Primer extension analysis. Determination of specific $c a b$ mRNA levels at indicated time points during a day. The oligonucleotides " $c a b 1 \mathrm{C}$ " (panel A), "cab 1" and "cab 4" (both panel B) were hybridized to total RNA extracts (panel A: $15 \mu \mathrm{g}$, panel B: $60 \mu \mathrm{g}$ ) isolated from tomato (VFNT LA 1221) leaves. Light/dark regimes were described in Material and Methods. Lane A: Primer extension product using total RNA from the cv. Gardeners Delight $(10 \mu \mathrm{g})$. Lane B: pBR322 digested with Hpa II. from tomato. The complexity of the $c a b$ gene family of tomato and the sequence similarities may make a precise quantitation of each mRNA type complicated. Recently, two laboratories investigating the level of expression of the members of the small subunit of RuBPC/Oase gene family in petunia reported conflicting results (Dean et al., 1987; Tumer et al., 1986). The discrepancy of the results is most likely due to the different methods used for the analysis. However, the primer extension technique which we have used has several advantages over the classical methods of Northern and dot blot hybridizations (Dean et al., 1987). With the primer extension method we have so far analysed 5 of 15 genes of the $c a b$ gene family of tomato. With this technique it was possible to define the transcription start sites of these five genes. The lengths of the untranslated leader regions of the mRNAs are in agreement with the sequences determined from cDNA clones. To verify the different transcription start sites it is necessary to analyse each individual $c a b$ gene by "S1 nuclease digestion" technique. In the case of hybridizations with oligonucleotide " $c a b$ $1 C$ " two primer extension products appeared (67 and 65 nucleotide length). This result may have different reasons (Williams and Mason, 1985). It is likely that this smaller reverse transcript is due to the so called "Cap effect", which is thought to be the result of premature termination of the reverse transcription at the methylated residue situated next to the cap site.

The primer extension technique also provides us with a reliable method to quantitate mRNA levels at different time points during a diurnal cycle. In young tomato leaves we were able to determine relative mRNA levels of the $c a b 1$ and $c a b 4$ genes. All transcripts appear to accumulate after 6 a.m., 
which correlates with the transition phase from darkness to illumination. This characteristic pattern is very similar to the pattern observed under the natural day/night regime (Piechulla, 1988). An additional aspect, however, may be interesting to note: The plants of experiment 5 (Fig. 5) were grown in the greenhouse with supplementary light (6 a.m. to 8 p.m.), but sunrise occurred at 4.29 a.m. Our data demonstrated, however, that no mRNA accumulation was detectable between $4.30 \mathrm{a} . \mathrm{m}$. and 6 a.m. This result is surprising, since Tavladoraki et al. (1989) were able to show that a 2 min red light pulse was sufficient to induce a rhythmic expression pattern of $c a b$ in Phaseolus vulgaris. Therefore, we assume that either the light quantity or light quality shortly after sunrise is not sufficient to induce $c a b$ mRNA accumulation to detectable levels. Additional control experiments of plants which were grown without supplementary light are under way.

In respect to the timing of $m$ RNA accumulation during a diurnal cycle different results were obtained in tomato and Petunia (Stayton et al., 1989). At least three of the five genes tested by Stayton et al. show significant transcript accumulation as much as $6 \mathrm{~h}$ prior to illumination. Similarly, in wheat the $c a b 1$ mRNA was detected $4 \mathrm{~h}$ before the dark/light transition (Nagy et al., 1988), while in tomato $c a b$ mRNA accumulation was observed after the dark/light transition. At present we do not understand the significance of this difference, but it may indicate that different types of regulatory mechanisms occur in different plant species. It seems plausible that in tomato leaves the initiation of expression of the $c a b 1$ and $c a b 4$ genes is strictly correlated with the appearance of light, while the mRNA accumulation in wheat and petunia is not so well synchronized with the environmental conditions. Another simple explanation may be that different experimental designs cause this discrepancy.

It should also be mentioned at this point that the primer extension products after annealing the oligonucleotide " $c a b$ 1" with total RNA from two different cherry tomato cultivars (VFNT LA 1221 and Gardeners Delight) appear in different quantities [see Figs. 4(A) and 5(B)]. While in the cv. Gardeners Delight the majority of the radioactive product was found in the $155 \mathrm{~b}$ long fragment, it was the 94 bases long reverse transcript in the case of cv. VFNT LA 1221. More detailed investigations are necessary, but it seems possible that the expression of the individual genes of a gene family is altered in different cultivars. However, the comparison of the genomic organizations and sequence analyses do not exhibit differences between tomato cultivars.

The information regarding the regulation of the rhythmic expression of the $c a b$ genes is at the present time very limited. We believe that this mechanism is inherited (Riesselmann and Piechulla, 1990) and builds the basis for further signals to function in a superimposed manner. This "biological clock" may have its physiological significance in the anticipation of the following day to allow optimal usage of the irradiation. Therefore, it is important to synchronize the expression of the important light harvesting proteins with the actual environmental conditions. Light or the duration of illumination was able to influence the amplitude of the expression, but did not determine the periodic length or the time points of maximum and minimum of period. These characteristic parameters of a circadian rhythm were specified by the light to dark transition phase (Meyer et al., 1990; Riesselmann and Piechulla, 1990). On the other hand, this system has to be flexible enough to react to the annual light/dark variability. The photoperiodic phenomenon has been the interest of many researchers for a long time. In this respect, most information has been collected for the flowering response and the correlated reproduction ability (for review VincePrue, 1986). The present study of the $c a b$ expression demonstrates clearly that photoperiodic responses are also manifested at the molecular level. At this point we can only describe this phenomenon of differential light sensibility, but the mechanism or the oscillator involved are not known.

In the past 2-3 years it has become clear that the mechanism(s) regulating the expression of the $c a b$ genes is not a simple process, but a rather complex regulation scheme is needed to explain the manifold $c a b$ expression patterns. In the case of the $c a b$ proteins and the small subunit of RuBPC/Oase, "light regulating elements (LRE)" had been defined on the nucleotide level (for review Kuhlemeier et al., 1987). Particular DNA binding proteins are required for light-dependent transcription of these photosynthesis-specific genes (Green et al., 1988; Guiliano et al., 1988). Since other components also influence the transcription of these genes, the present model describes a linear organization of different cis-acting elements upstream of the coding region of a gene. The knowledge of (i) the existance of a circadian rhythm/oscillator influencing $c a b$ gene expression and (ii) the coordinated expression of 15 individual genes of this gene family suggest that this model is even more complicated. At present we are still far away from understanding this network of events and hierarchic organization that play a role in the regulation of $c a b$ gene expression in tomato.

Acknowledgements-The authors thank Mrs. Hourticolon for her help in preparing the figures and Mrs. Lechte, Mr. Lange and Mr. Hansmann for cultivating the tomato plants. This work was supported by a grant of the DFG given to B.P. (Pi 153/2-3), a fellowship of the Graduiertenförderung of the University of Göttingen to J.-W.K. and a grant for collaborative research of the NATO.

\section{REFERENCES}

Darr, S. C., S. C. Sommerville and C. J. Arntzen (1986) Monoclonal antibodies to the light-harvesting chloro- 
phyll $a / b$ protein complex of photosystem II. J. Cell Biol. 103, 731-740.

Dean, C., M. Favreau, P. Dunsmuir and J. Bedbrook (1987) Confirmation of the relative expression levels of the Petunia (Mitchell) rbcS genes. Nucleic. Acid Res. 15, 4655-4668.

Dean, C., M. Favreau, P. Dunsmuir and J. Bedbrook (1987) Confirmation of the relative expression levels of the Petunia (Mitchell) rbcS genes. Nucl. Acid Res. 15, $4655-4668$.

Evans, P. K. and J. M. Anderson (1986) The chlorophyll $a / b$ proteins of PSI and PSII are immunological related. FEBS Lett. 199, 227-233.

Giuliano, G., N. E. Hoffmann, K. Ko, P. A. Scolnik and A. R. Cashmore (1988a) A light-entrained circadian clock controls transcription of several plant genes. EMBO J. 7, 3635-3642.

Giuliano, G., E. Pichersky, V. S. Malik, M. P. Timko, P. A. Scolnik and A. R. Cashmore (1988b) An evolutionary conserved protein binding sequence upstream of a plant light-regulated gene. Proc. Natl. Acad. Sci. U.S.A. 85, 7089-7093.

Green, P. J., M. H. Yong, M. Cuoyyo, Y. Kano-Marakami, P. Silverstein and N. H. Chua (1988) Binding site requirements for pea nuclear protein factor GT-1 correlate with sequences required for light-dependent transcriptional activation of the $r b c S 3 \mathrm{~A}$ gene. $E M B O$ J. 7, 4035-4044.

Hoffmann, N. E., E. Pichersky, V. S. Malik, C. Castresana, K. Ko, S. C. Darr and A. R. Cashmore (1987) The nucleotide sequence of a tomato cDNA clone encoding a photosystem I protein with homology to photosystem II chlorophyll $a / b$-binding polypeptides. Proc. Natl. Acad. Sci. U.S.A. 84, 8844-8848.

Kloppstech, K. (1985) Diurnal and circadian rhythmicity in the expression of light-induced plant nuclear messenger RNAs. Planta (165) 65, 502-506.

Kuhlemeier, C., P. J. Green and N. H. Chua (1987) Regulation of gene expression in higher plants. Ann. Rev. Plant Physiol. 38, 221-255.

Maniatis, T., E. F. Fritsch and J. Sambrook (1982) $\mathrm{Mol}$ ecular Cloning: A Laboratory Manual, p. 196. Cold Spring Harbor Laboratory Press, Cold Spring Harbor, NY.

Meyer, H., U. Thienel and B. Piechulla (1990) Molecular characterization of the diurnal/circadian expression of the chlorophyll $a / b$ binding proteins in leaves of tomato and other dicotyledonous and monocotyledonous plant species. Planta 180, 5-15.

Nagy, F., S. A. Kay and N. H. Chua (1988) A circadian clock regulates transcription of the wheat $c a b-1$ gene. Genes Dev. 2, 376-382.

Paulsen, H. and L. Bogorad (1988) Diurnal and circadian rhythms in the accumulation and synthesis of mRNA for the light-harvesting chlorophyll $a / b$ binding protein in tobacco. Plant Physiol. 88, 1104-1109.

Pichersky, E., R. Bernatzky, S. D. Tanksley, R. W. Breidenbach, A. P. Kausch and A. R. Cashmore (1985) Molecular characterization and genetic mapping of two clusters of genes encoding chlorophyll $a / b$-binding proteins in Lycopersicon esculentum (tomato). Gene 40, 247-258.

Pichersky, E., T. G. Brock, D. Nguyen, N. E. Hoffman, B. Piechulla, S. D. Tanksley and B. R. Green (1989) A new member of the $c a b$ gene family: structure, expression and chromosomal location of $c a b-8$, the tom- ato gene encoding the type III chlorophyll $a / b$-binding polypeptide of photosystem I. Plant Mol. Biol. 12, 257-270.

Pichersky, E., N. E. Hoffmann, R. Bernatzky, B. Piechulla, S. D. Tanksley and A. R. Cashmore (1987a) Molecular characterization and genetic mapping of DNA sequences encoding the type I chlorophyll $a / b$ binding polypeptide of photosystem $I$ in Lycopersicon esculentum (tomato). Plant Mol. Biol. 9, 205-216.

Pichersky, E., N. E. Hoffmann, V. S. Malik, R. Bernatzky, S. D. Tanksley, L. Szabo and A. R. Cashmore (1987b) The tomato $c a b-4$ and $c a b-5$ genes encode a second type of $c a b$ polypeptides localized in photosystem II. Plant Mol. Biol. 9, 109-120.

Pichersky, E., S. D. Tanksley, B. Piechulla, M. M. Stayton and P. Dunsmuir (1988) Nucleotide sequence and chromosomal location of $c a b-7$, the tomato gene encoding the type II chlorophyll $a / b$-binding polypeptide of photosystem I. Plant Mol. Biol. 11, 69-71.

Piechulla, B. (1988) Plastid and nuclear mRNA fluctuations in tomato leaves - diurnal and circadian rhythms during extended dark and light periods. Plant Mol. Biol. 11, 345-353.

Piechulla, B. (1989) Changes of the diurnal and circadian (endogenous) mRNA oscillations of the chlorophyll $a / b$ binding protein in tomato leaves during altered day/ night (light/dark) regimes. Plant Mol. Biol. 12, 317-327.

Piechulla, B. and W. Gruissem (1987) Diurnal mRNA fluctuations of nuclear and plastid genes in developing tomato fruits. EMBO J. 6, 3593-3599.

Piechulla, B., E. Pichersky, A. R. Cashmore and W. Gruissem (1986) Expression of nuclear and plastid genes for photosynthesis-specific proteins during tomato fruit development and ripening. Plant Mol. Biol. 7, 367-376.

Riesselmann, S. and B. Piechulla (1990) Effect of dark phases and temperature on the chlorophyll $\mathrm{a} / \mathrm{b}$ binding protein mRNA level oscillations in tomato seedlings. Plant Mol. Biol. In press.

Spiller, S. C., L. S. Kaufman, W. F. Thompson and W. R. Briggs (1987) Specific mRNA and rRNA levels in greening pea leaves during recovery from ironstress. Plant Physiol. 84, 409-411.

Stayton, M. M., P. Brosio and P. Dunsmuir (1989) Photosynthetic genes of Petunia (Mitchell) are differentially expressed during the diurnal cycle. Plant Physiol. 89, $776-782$.

Tavladoraki, P., K. Kloppstech and J. Argyroudi-Akoyunoglou (1989) Circadian rhythm in the expression of the mRNA coding for the apoprotein of the light-harvesting complex of photosystem II. Plant Physiol. 90, 665-672.

Taylor, W. C. (1989) Transcriptional regulation by a circadian rhythm. Plant Cell 1, 259-264.

Tumer, N. E., W. G. Clark, G. J. Tabor, C. M. Hironaka, R. T. Fraley and D. M. Shah (1986) The genes encoding the small subunit of ribulose-1,5-bisphosphate carboxylase are expressed differentially in petunia leaves. Nucleic Acid Res. 14, 3325-3342.

Vince-Prue, D. (1986) The duration of light and photoperiodic responses. In Photomorphogenesis in Plants (Edited by R. E. Kendrick and G. H. M. Kronenberg), pp. 269-305. Martinus Nijhoff/Junk, Dordrecht.

Williams, J. G. and P. J. Mason (1985) Hybridisation in the analysis of RNA. In Nucleic Acid Hybridization, $A$ Practical Approach (Edited by B. D. Hames and S. J. Higgins), pp. 152-160. IRL Press, Oxford. 